\title{
Where the cell cycle and histones meet
}

\author{
Mark E. Ewen ${ }^{1}$ \\ Dana-Farber Cancer Institute and Harvard Medical School, Boston, Massachusetts 02115, USA
}

Since the discovery of mammalian cyclin E and the Dtype cyclins in 1991, much effort has been devoted towards elucidating their role in $\mathrm{G}_{1}$ progression and $\mathrm{S}$ phase entry. Key to this endeavor has been the identification and characterization of substrates for cyclin E-CDK2 and D-type cyclin-CDK4 and cyclin-CDK6 complexes. Whereas there appears to be only one critical substrate of CDK4 and CDK6, the list of CDK2 substrates continues to lengthen in line with the realization that the principal mediators of cyclin E-CDK2 action are yet to be identified. The papers by $\mathrm{Ma}$ et al. and Zhao et al. in this issue bring a new dimension to our understanding of cyclin E-CDK2, by showing that NPAT, a previously identified CDK2 substrate, links the cell cycle to histone gene transcription. This provides us with the beginnings of how the action of CDKs is linked to the periodic synthesis of histones in mammalian cells. These works illuminate our picture of how the cell cycle control elements may influence multiple biosynthetic processes as integral to $S$ phase as duplication of the genetic material itself.

\section{Cyclins and CDKs}

The cell cycle is the process through which cells duplicate themselves. The holistic view of the cell cycle of decades ago predicts that this duplication must involve not only synthesis of a copy of the genetic material but a doubling of the ancillary components of the genome and the cell's biomass (Mitchison 1971). The discovery of the key cell cycle regulatory elements, the cyclins and CDKs, has allowed us to understand how initiation of DNA synthesis is controlled. How the other processes of cellular duplication are regulated remains elusive.

The principle CDKs responsible for $\mathrm{G}_{1}$ progression and entrance into $\mathrm{S}$ phase are CDK2, CDK3, CDK4, and CDK6. The D-type cyclins (D1, D2, and D3) are the regulatory subunits for CDK4/6 and their synthesis is characterized as a delayed early response (early/mid $\mathrm{G}_{1}$ ) to mitogen stimulation. Cyclin $\mathrm{E}$, which activates CDK2 and possibly CDK3, is expressed in late $\mathrm{G}_{1}$ and early $\mathrm{S}$ phase (Dulic et al. 1992; Koff et al. 1992; Ohtsubo and

${ }^{1}$ E-MAIL mark_ewen@dfci.harvard.edu; FAX (617) 632-5417. Article and publication are at www.genesdev.org/cgi/doi/10.1101/ gad.842100.
Roberts 1993). Cyclin A can also activate CDK2, but is essential later, at the $G_{1} / S$ boundary and throughout $S$ phase (Girard et al. 1991; Pagano et al. 1992; Zindy et al. 1992). Thus, CDK4/6 are activated in mid $\mathrm{G}_{1}$ and CDK2 in late $G_{1}$. The coordinate action of the $G_{1}$ CDKs triggers events required for $S$ phase. Identification of the substrates of the various CDKs has allowed us to gain a deeper understanding of how these enzymes exert their influence.

\section{A substrate for CDK4 and CDK6}

The major substrate of D-type cyclin-CDK4/6 complexes is the retinoblastoma protein, $\mathrm{pRb}$ (for review, see Sherr 1993, 1994). The importance of $\mathrm{pRb}$ phosphorylation in $\mathrm{G}_{1}$ progression is underscored by two observations. First, curtailment of cyclin D1 expression or neutralization of its activity only arrests cells when $\mathrm{pRb}$ is functional. Second, ectopic expression of the CDK4/6specific inhibitor $\mathrm{p} 16^{\mathrm{INK} 4 \mathrm{a}}$ requires functional $\mathrm{pRb}$ to impose a $G_{1}$ arrest. Thus, the first molecular event involving the actions of a CDK required for $G_{1}$ progression is phosphorylation of a substrate, $\mathrm{pRb}$, by D-type cyclinCDK4/6 complexes (Fig. 1).

The means by which pRb exerts control over cell cycle progression is thought to be its association with the E2F family of transcription factors (for review, see Dyson 1998; Nevins 1998). This regulation occurs by one of two mechanisms: (1) pRb can bind to the transcriptional activation domain of E2F, thereby blocking its activation; and (2) transcription from promoters containing E2F sites can be actively repressed by complexes containing $\mathrm{E} 2 \mathrm{~F}, \mathrm{pRb}$, and HDAC and SWI/SNF family members. Many of the genes that are required for DNA synthesis contain E2F sites in their promoters. Among these are enzymes required for the synthesis of DNA precursors such as dihydrofolate reductase and thymidine kinase, proteins involved in the synthesis of DNA exemplified by Pol $\alpha$, proteins essential for the establishment of the pre-replication complex like HsCdc6 and MCM proteins, and proteins required for the formation of chromatin, specifically histone $\mathrm{H} 2 \mathrm{~A}$.

\section{Sequential action of CDK4 and CDK6, and CDK2}

Cyclin $\mathrm{E}$ is included in the list of E2F target genes, and herein lies the link between the regulation of $\mathrm{pRb}-\mathrm{E} 2 \mathrm{~F}$ complexes by D-type cyclins and the activation of CDK2 


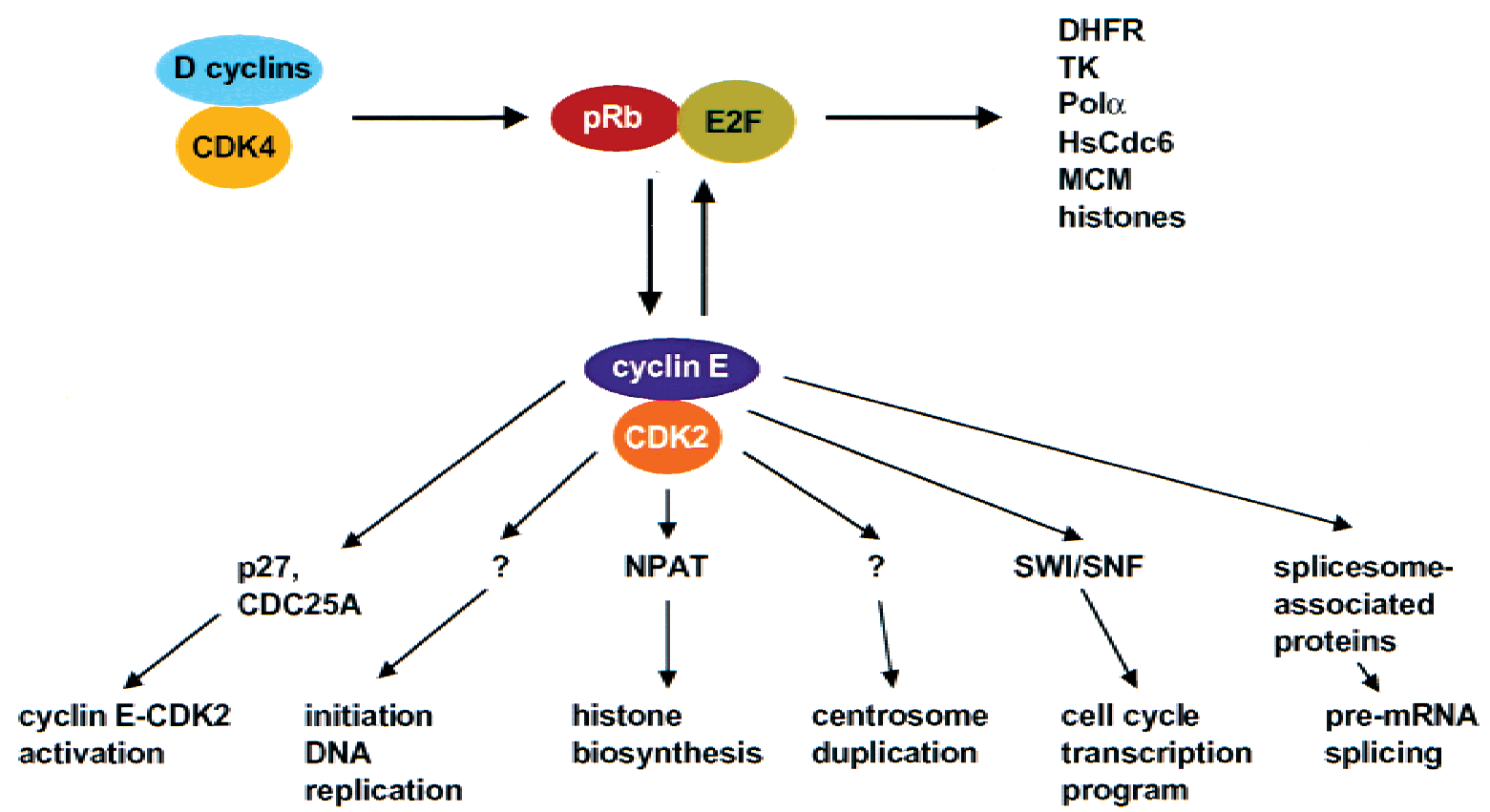

Figure 1. Pathways through which CDK4 and CDK2 promote $\mathrm{G}_{1}$ progression and $\mathrm{S}$ phase entry. CDK4 together with its regulatory partners, the D-type cyclins, mediate the phosphorylation of the retinoblastoma protein, $\mathrm{pRb}$. This event partially abrogates the ability of $\mathrm{pRb}-\mathrm{E} 2 \mathrm{~F}$ complexes to negatively regulate the transcription of certain genes required for $\mathrm{S}$ phase entry. Among these is cyclin $\mathrm{E}$, the regulatory subunit of CDK2. Cyclin E-CDK2 kinase participates in a number of processes at the $\mathrm{G}_{1} / \mathrm{S}$ transition. Among these are the activation of CDK2 itself, the full inactivation of $\mathrm{pRb}$, thereby modifying further the E2F transcriptional program, histone biosynthesis, pre-mRNA splicing, the initiation of DNA replication and centrosome duplication.

(Ohtani et al. 1995; Botz et al. 1996; Geng et al. 1996). The relationship between cyclin $\mathrm{E}$ and $\mathrm{pRb}$ is presently controversial and there are currently two models. In one, the initial phosphorylation of $\mathrm{pRb}$ by CDK4/6 partially inactivates its negative regulatory functions. This inactivating event, however, is sufficient to facilitate cyclin E expression. This in turn allows for subsequent phosphorylation of $\mathrm{pRb}$ by cyclin E-CDK2 complexes leading to its full inactivation (Fig. 1). This scheme derives from the observation that CDK4/6-mediated phosphorylation of $\mathrm{pRb}$ is a prerequisite for subsequent phosphorylation by CDK2 (Lundberg and Weinberg 1998). In addition, there are data showing that when $\mathrm{pRb}$ is phosphorylated by only CDK4/6 it retains the ability to bind to E2F and regulate transcription (Ezhevsky et al. 1997). Lastly, recent studies have begun to dissect how CDK4/6 and CDK2 differentially affect pRb-E2F activity. CDK4-mediated phosphorylation of $\mathrm{pRb}$ relieves its repression on cyclin $E$ transcription but not on other genes required later in the cell cycle, such as cyclin $A$ and $C d c 2$. This is achieved through the dissociation of HDAC from $\mathrm{pRb}$ leaving the transcriptional repressor functions of $\mathrm{pRb}-$ SWI/SNF-E2F complexes intact. The subsequent activation of cyclin E-CDK2 then fully inactivates pRb-mediated transcriptional repression by either targeting $\mathrm{pRb}$ or SWI/SNF (Shanahan et al. 1999; Zhang et al. 2000). Thus, CDK4/6 and CDK2 differentially affect the ability of $\mathrm{pRb}$ to influence gene transcription. This allows the various CDKs to alter the transcriptional program mediated by pRb-E2F during $G_{1}$ and $S$ phase as a function of their sequential activation. Implicit here is that the only function of cyclin $\mathrm{E}$ is to complete the inactivation of $\mathrm{pRb}$, with the subsequent relief of transcriptional repression responsible for its ultimate effects.

In the other model, cyclin E exerts its influence directly via CDK2's substrates other than $\mathrm{pRb}$. Evidence supporting this notion derives from the observation that ectopic expression of cyclin $\mathrm{E}$ in cultured mammalian cells can bypass the need for $\mathrm{pRb}$ inactivation during progression from $G_{1}$ to $S$ phase (Leng et al. 1997; Lukas et al. 1997). In addition, replacing the cyclin $D 1$ gene with cyclin $E$ in the mouse (cyclin E $\rightarrow \mathrm{D} 1$ "knockin") essentially rescues all of the phenotypes associated with cyclin D1-deficiency, although the degree of $\mathrm{pRb}$ phosphorylation is no greater than that in the cyclin D1-deficient animal. An interpretation of this result is that the sole function of cyclin D1 is to facilitate the synthesis of cyclin $\mathrm{E}$, and that the ability of cyclin E-dependent kinase to phosphorylate $\mathrm{pRb}$ is not absolutely required for manifestation of its influence (Geng et al. 1999). The existence of critical CDK2 substrates other than $\mathrm{pRb}$ is a direct prediction of this model. Both mechanisms have attractive features and ultimately, both probably participate.

\section{Beyond pRb}

Implicit in the observation that ectopic cyclin E can bypass $\mathrm{pRb}$ 's cell cycle function is that cyclin E performs critical functions beyond $\mathrm{pRb}$ phosphorylation. The first 
evidence for this resides in the demonstration that inactivation of cyclin E results in $\mathrm{G}_{1}$ arrest in cells in which $\mathrm{pRb}$ function is inactivated by expression of SV40 large T antigen (Ohtsubo et al. 1995). In addition, inhibition of CDK2 activity by ectopic expression of CDK inhibitors, such as p21 and p27, or a dominant-negative CDK2 mutant arrests the cell cycle in $\mathrm{G}_{1}$ without $\mathrm{pRb}$ 's contrivance (van den Heuvel and Harlow 1993; Sherr and Roberts 1995; Hofmann and Livingston 1996). Much effort has since been devoted to determining the cell cyclepromoting functions of CDK2 during the $\mathrm{G}_{1} / \mathrm{S}$ transition. This has involved the identification of key cellular processes that CDK2 is involved in and its substrates whose phosphorylation precipitates these events (Fig. 1).

Like CDK4/6, CDK2 regulates the transcriptional program of the cell. CDK2-mediated phosphorylation has been linked to the activity of E2F. Stable association of cyclin A-dependent but not cyclin E-dependent kinase with E2F-1 results in transphosphorylation of DP-1, a heterodimeric partner of E2Fs, resulting in a block to DNA binding of the E2F-1/DP-1 complex (Krek et al. 1994; Dynlacht et al. 1995). This might provide a means to regulate the duration of E2F activity once cells have entered S phase. In addition, cyclin E-CDK2-mediated phosphorylation of E2F-5 can potentiate its activation (Morris et al. 2000). This occurs by phosphorylation-dependent recruitment of the p300/CBP co-activators. Thus, CDK2 appears to participate in the timely activation and deactivation of E2F function.

The CDK inhibitor p27 can inactivate the cyclin E-CDK2 complex. However, p27 is also a cyclin E-CDK2 substrate. Phosphorylation of p27 at the hands of the kinase targets the inhibitor for degradation (Mantagnoli et al. 1999). Thus, CDK2 antagonizes the action of its own inhibitor. p27 levels are normally high in quiescent cells and then decline during $G_{1}$ progression. It has been proposed that once active cyclin E-CDK2 reaches a critical threshold level it initiates a positive feedback loop leading to the elimination of $\mathrm{p} 27$. This allows CDK2 to make a transition from low to high activity, thereby promoting progression from $G_{1}$ to $S$ phase (Sheaff et al. 1997).

The phosphatase CDC25A is essential for S phase entry and is thought to play a role in the activation of cyclin E-CDK2 by dephosphorylating specific residues in CDK2 (Hoffmann et al. 1994; Jinno et al. 1994). Cyclin E-CDK2 can associate with and phosphorylate CDC25A leading to its activation. In this setting CDC25A and cyclin E-CDK2 participate in a positive-feedback loop.

Cyclin E associates with components of the premRNA splicing machinery, and spliceosome-associated proteins have been shown to be substrates for cyclin E-CDK2 in vitro (Seghezzi et al. 1998). How CDK2-mediated phosphorylation events influence pre-mRNA splicing remains to be determined. However, one possibility is that the influence of CDK2 on global splicing may promote biosynthesis. Alternatively, it may operate in a pathway influencing the splicing of particular mRNAs whose function influences the $\mathrm{G}_{1} / \mathrm{S}$ transition (Seghezzi et al. 1998).
In a somatic mammalian cell-free system CDK2 can participate directly in the initiation of DNA replication. Specifically, recombinant cyclin E-CDK2 and cyclin A-CDK2 can trigger the initiation of DNA synthesis in $\mathrm{G}_{1}$ nuclei as efficiently as addition of an $\mathrm{S}$ phase nuclear extract (Krude et al. 1997). Similar results have been reached in Xenopus (Jackson et al. 1995). How CDK2 complexes trigger the initiation of DNA replication is not understood. However, it has been demonstrated that CDK2 can phosphorylate HsCdc6. Although HsCdc6 clearly has a role in the initiation of DNA synthesis, whether its phosphorylation by CDK2 participates in this process is controversial (Herbig et al. 1999; Jiang et al. 1999; Petersen et al. 1999). Results from yeast and mammalian systems point to the possibility that phosphorylation of Cdc6 prevents the reassembly of the prereplication complex ensuring that the genome is only replicated once per cell cycle. Clearly, the identification of CDK2 targets that directly participate in the initiation of DNA replication will greatly facilitate understanding how this process is coordinated with the rest of the cell cycle.

The centrosomes are cellular structures critical for proper chromosome segregation during mitosis. The centrosomes themselves are duplicated during $S$ phase. Recently, centrosome duplication in Xenopus egg extracts was shown to require the activity of cyclin E-CDK2 (Hinchliffe et al. 1999; Lacey et al. 1999). Similarly, centrosome duplication in somatic mammalian cells was shown to require the activity of cyclin A-CDK2 and the activity of E2F (Meraldi et al. 1999). The results link the action of CDK2 to one of the key features of cell division. The substrate of CDK2 involved in centrosome duplication remains to be identified.

The preceding discussion raises the question of what constitutes an important cyclin E-CDK2 substrate. Clearly, the best candidates are those whose actions need to be modulated as a function of cell cycle position-specifically, coincident with cyclin E-CDK2 activity-and whose functions can account for the ability of cyclin E to promote cell cycle progression. p27 is thus a good candidate because its degradation following modification by the cyclin E kinase seems likely to contribute to progress in the cell cycle. A similar statement can be made for CDC25A. The substrate mediating centrosome duplication is another example. Clearly, this process is essential for cellular reproduction and it is temporally matched with kinase activity. Likewise, the element that acts as the intermediary of cyclin $\mathrm{E}$ in the initiation of DNA replication meets the criteria. These observations indicate that we already have a fairly good idea of the processes in which cyclin E-CDK2 is involved. However, the substrates that CDK2 must phosphorylate to execute the majority of these events, for example, centrosome duplication, remain to be identified. Only once this has been achieved can we ask the hardest question of a substrate, namely, whether its modification is necessary for the manifestation of cyclin E's role in cell proliferation. In this regard, it is possible and even likely that cyclin E-dependent kinase must phosphorylate mul- 
tiple substrates in order to bring about events which, in sum, comprise its biological function.

\section{Histone biosynthesis}

The defining feature of $\mathrm{S}$ phase is replication of the genome. Because histones constitute half of the mass of chromatin, their timely biosynthesis is clearly also a critical event during this phase of the cell cycle. Histones play a crucial role in the packaging of DNA and allow for efficient replication and segregation of chromosomes. The papers by Ma et al. (2000) and Zhao et al. (2000) make a significant contribution to our understanding of how histone gene transcription is coordinated with the cell cycle and the participation of cyclin E-CDK2 in this process.

The abundance of histone mRNA is increased $25-$ 30 -fold during $\mathrm{S}$ phase. The regulation of histone transcript levels occurs at three major levels, transcription, pre-mRNA processing involving endonucleolytic cleavage at the $3^{\prime}$ termini, and stability mediated through a $3^{\prime}$ stem-loop structure (for review, see Heintz 1991; Osley 1991). The relative contribution of these processes to the induction of histone biosynthesis at the $G_{1} / S$ boundary, and its decline in $G_{2}$, vary depending on experimental methodologies, but increases in transcription are generally thought to account for a 3-10-fold increase in mRNA levels as cells progress into $S$ phase.

The mammalian core histone genes-H2A, H2B, H3, and $H 4$ - and the linker $H 1$ reside in heterogeneous clusters. Histone gene promoters generally contain a core promoter for proper initiation by RNA polymerase II, a subtype-specific consensus element (SSCE) and a distal activation domain. In the case of $\mathrm{H} 4$ and $\mathrm{H} 2 \mathrm{~B}$, the most extensively studied, the SSCE confers cell cycle-dependent promoter activity. In contrast to yeast, where the transcription of all histone genes is regulated by the same elements, the regulation of each of the mammalian histone genes involves different cis-acting DNA elements and multiple factors. The importance of the coordinate regulation of the histone genes is underscored by the observation that, in yeast, overexpression of histone $H 2 A$ and $H 2 B$ or $H 3$ and $H 4$ results in an increased frequency of chromosome loss (Meeks-Wagner and Hartwell 1986). This suggests that the appropriate balance of the four core histones is required for the accurate assembly of chromatin. The challenges for the field have been twofold: To determine how the cell cycle dependency of histone gene transcription is conferred, and how transcription of each gene is coordinated with that of the others.

NPAT was identified in a screen for proteins that could interact with cyclin E-CDK2 and was subsequently shown to be a legitimate substrate for this kinase both in vitro and in vivo (Zhao et al. 1998). NPAT is expressed throughout the cell cycle with maximal expression at the $\mathrm{G}_{1} / \mathrm{S}$ boundary. These findings together with the observation that ectopic expression of NPAT can accelerate progression from $G_{1}$ into $S$ phase made it reasonable to think of NPAT as a bona fide target of cyclin E-CDK2, with complicity in the execution of S phase.

The critical breakthrough into understanding NPAT function came from the study of its subcellular localization. NPAT and cyclin E-CDK2 colocalize to discrete foci identified as Cajal (or coiled) bodies and although the function of these cellular structures is not known, identification of some of their components (e.g., pol II, TFIIF, splicing snRNAs) suggests that they may be sites for assembly of complexes involved in transcription and splicing (Gall et al. 1999). Cajal bodies have also been reported to associate with histone gene clusters (Frey and Matera 1995). What the papers by Zhou et al. (2000) and Ma et al. (2000) show is that NPAT is involved in cell cycle-dependent transcriptional regulation of histone $H 2 B, H 4$, and $H 3$ and that this function is influenced by its phosphorylation by cyclin E-CDK2.

The result suggests that a principal cell cycle regulatory complex has a hand in the induction of histone gene transcription at the $\mathrm{G}_{1} / \mathrm{S}$ boundary. This provides an attractive solution for how histone gene transcription is regulated around the cogs of the cell cycle machine. In addition, the two reports also suggest that a single factor, NPAT, is involved in the transcriptional control of at least three of the four core histone genes, thus giving us a glimpse of how the induction of each of the histone genes might be coordinated at the beginning of $S$ phase.

A number of questions arise from the two papers. The most immediate is how NPAT actually contributes to the transcription of histone genes. The finding that mutation of the octamer binding element (which Oct-1 binds to) in the $H 2 B$ promoter diminishes NPAT-mediated stimulation of transcription is intriguing. It suggests that NPAT is in some way dependent on Oct-1 binding for its function. The regulation of Oct-1-mediated transcriptional activation is poorly understood (Tanaka and Herr 1990), although it is known that its DNA binding activity is not altered as cells progress towards $S$ phase. It has been proposed that protein-protein interactions modulate the activity of Oct-1 because association with VP-16 is required for Oct-1-dependent CMV immediate early gene transcription (Osley 1991). Whether NPAT and Oct-1 interact, either directly or indirectly, and the possible role of cyclin E-CDK2-mediated NPAT phosphorylation in this process remains to be determined. This may not be too far-fetched an idea, however. Earlier work has demonstrated that the pattern of Oct-1 phosphorylation changes as a function of cell cycle position, and some of these phosphorylation events are thought to be CDK-mediated (Roberts et al. 1991).

Despite the elucidation of a role for NPAT in histone biosynthesis, it is clear that we need to learn more about its role in cell cycle progression. Although both groups provide evidence that cyclin E-CDK2-mediated phosphorylation of NPAT is involved in its ability to positively regulate histone gene transcription, the strict dependence on these events for cell cycle progression is not yet set in concrete. Perhaps there is an additional layer of complexity in the connection between cyclin E-CDK2, 
NPAT, and histones, and it will be a challenge for the field to establish these finer points.

\section{On time, and together}

It is now apparent that cyclin E-CDK2 participates in at least two major processes needed for the generation of chromatin, the initiation of DNA replication and the biosynthesis of various histone subtypes. The need to coordinate these two events with the rest of the cell cycle makes sense, but that the regulation of these processes are so intimately linked is also perhaps not a surprise. Histone biosynthesis is so tightly synchronized with DNA synthesis that the pool of free histones is virtually non-existent in proliferating cells because they are produced at levels matching that required for the assembly of chromatin (Osley 1991).

The analysis of cyclin E-CDK2 function indicates that this enzyme directly catalyzes a number of events required for the $G_{1} / S$ transition to take place in a coordinated fashion. That ectopic expression of cyclin $\mathrm{E}$ in cultured mammalian cells results in chromosomal instability seems to add credence to the notion of cyclin $\mathrm{E}$ as the arbiter of "on time and together" (Spruck et al. 1999). However, the observation that cyclin $\mathrm{E} \rightarrow \mathrm{D} 1$ knockin mice apparently suffer no ill-effects of having cyclin $\mathrm{E}$ expressed out of sequence must make us wonder about the importance of events brought about by cyclin E-CDK2, as well as the importance of their timing.

The identification and characterization of CDK4, CDK6, and CDK2 substrates, in addition to providing us with an understanding of how $\mathrm{G}_{1}$ progression and $\mathrm{S}$ phase entry are regulated, has also taught us about two very different flavors of kinase operation. CDK4/6, together with their regulatory partners, have but one substrate, $\mathrm{pRb}$. Their influence then, although far reaching, is exerted by proxy through $\mathrm{pRb}$ and its downstream targets. By comparison, the number of CDK2 substrates is large. Furthermore, although CDK2, like CDK4/6, does initiate a cascade of events by, for example, influencing the function of transcription factors, it also has the capacity to execute its powers first hand by direct participation in histone biosynthesis, DNA replication, and centrosome duplication. As the list of CDK2 substrates grows we may begin to see cyclin E more as the micromanager of disparate aspects of chromatin replication than as a master regulator.

\section{Acknowledgments}

I thank Justin Lamb for stimulating conversation and Justin Lamb, Christine McMahon, Kornelia Polyak, and William Sellers for critical review of this manuscript.

\section{References}

Botz, J., Zerfass-Thome, K., Spitkovsky, D., Delius, H., Vogt, B., Eilers, M., Hatzigeorgiou, A., and Jansen-Durr, P. 1996. Cell cycle regulation of the murine cyclin $\mathrm{E}$ gene depends on an
E2F binding site in the promoter. Mol. Cell. Biol. 16: 34013409.

Dulic, V., Lees, E., and Reed, S.I. 1992. Association of human cyclin $\mathrm{E}$ with a periodic $\mathrm{G}_{1}-\mathrm{S}$ phase protein kinase. Science 257: 1958-1961.

Dynlacht, B.D., Flores, O., Lees, J.A., and Harlow, E. 1995. Differential regulation of E2F trans-activation by cyclin/cdk2 complexes. Genes \& Dev. 8: 1772-1786.

Dyson, N. 1998. The regulation of E2F by pRB-family proteins. Genes \& Dev. 12: 2245-2262.

Ezhevsky, S.A., Hagahara, H., Vocero-Akbani, A.M., Gius, D.R., Wei, M.C., and Dowdy, S.F. 1997. Hypo-phosphorylation of the retinoblastoma protein $(\mathrm{pRb})$ by cyclin $\mathrm{D}: \mathrm{Cdk} 4 / 6 \mathrm{com}-$ plexes results in active pRb. Proc. Natl. Acad. Sci. USA 94: 10699-10704.

Frey, M.R. and Matera, G. 1995. Coiled bodies contain U7 small nuclear RNA and associate with specific DNA sequences in interphase human cells. Proc. Natl. Acad. Sci. USA 92: 5915-5919.

Gall, J.G., Bellini, M., Wu, Z., and C. Murphy. 1999. Assembly of the nuclear transcription and processing machinery: Cajal bodies (coiled bodies) and transcriptosomes. Mol. Biol. Cell 10: 4385-4402.

Geng, Y., Eaton, E.N., Picon, M., Roberts, J.M., Lundberg, A.S., Gifford, A., Sardet, C., and Weinberg, R.A. 1996. Regulation of cyclin E transcription by E2Fs and retinoblastoma protein. Oncogene 16: 2402-2407.

Geng, Y., Whoriskey, W., Park, M.Y., Bronson, R.T., Medema, R.H., Li, T., Weinberg, R.A., and Sicinski, P. 1999. Rescue of cyclin D1 deficiency by knockin cyclin E. Cell 97: 767-777.

Girard, F., Strausfeld, U., Fernandez, A., and Lamb, N.J.C. 1991. Cyclin A is required for the onset of DNA replication in mammalian fibroblasts. Cell 67: 1169-1179.

Heintz, N. 1991. The regulation of histone gene expression during the cell cycle. Biochim. Biophys. Acta. 1088: 327-339.

Herbig, U., Marlar, C.A., and Fanning, E. 1999. The Cdc6 nucleotide-binding site regulates its activity in DNA replication in human cells. Mol. Biol. Cell 10: 2631-2645.

Hinchliffe, E.H., Li, C., Thompson, E.A., Maller, J.L., and Sluder, G. 1999. Requirement of Cdk2-cyclin E activity for repeated centrosome reproduction in Xenopus eggs extracts. Science 283: 851-854.

Hoffmann, I., Draetta, G., and Karsenti, E. 1994. Activation of the phosphatase activity of human cdc25A by cdk2-cyclin $\mathrm{E}$ dependent phosphorylation at the $\mathrm{G}_{1} / \mathrm{S}$ transition. EMBO $J$. 13: 4302-4310.

Hofmann, F. and Livingston, D.M. 1996. Differential effects of $\mathrm{cdk} 2$ and cdk3 on the control of $\mathrm{pRb}$ and E2F function during $\mathrm{G}_{1}$ exit. Genes \& Dev. 10: 851-861.

Jackson, P.K., Chevalier, S., Philippe, M., and Kirschner, M.W. 1995. Early events in DNA replication require cyclin E and are blocked by p21CIP1. J. Cell Biol. 130: 755-769.

Jiang, W., Wells, N.J., and Hunter, T. 1999. Multistep regulation of DNA replication by Cdk phosphorylation of HsCdc6. Proc. Natl. Acad. Sci. USA 96: 6193-6198.

Jinno, S., Suto, K., Nagata, A., Igarashi, M., Kanaoka, Y., Nojima, H., and Okayama, H. 1994. Cde25A is a novel phosphatase functioning early in the cell cycle. EMBO $J$. 13: 1549-1556.

Koff, A., Giordano, A., Desai, D., Yamashita, K., Harper, J.W., Elledge, S., Nishimoto, T., Morgan, D.O., Franza, B.R., and Roberts, J.M. 1992. Formation and activation of a cyclin E-CDK2 complex during the $\mathrm{G}_{1}$ phase of the human cell cycle. Science 257: 1689-1694.

Krek, W., Ewen, M.E., Shirodkar, S., Arany, Z., Kaelin, W.G.J., and Livingston, D.M. 1994. Negative regulation of the 
growth-promoting transcription factor E2F-1 by a stably bound cyclin A-dependent protein kinase. Cell 78: 161-172.

Krude, T., Jackman, M., Pines, J., and Lasky, R.A. 1997. Cyclin/ Cdk-dependent initiation of DNA replication in a human cell-free system. Cell 88: 109-119.

Lacey, K.R., Jackson, P.K., and Stearns, T. 1999. Cyclin-dependent kinase control of centrosome duplication. Proc. Natl. Acad. Sci. USA 96: 2817-2822.

Leng, X., Connell-Crowley, L., Goodrich, D., and Harper, J.W. 1997. S-phase entry upon ectopic expression of $G_{1}$ cyclindependent kinases in the absence of retinoblastoma protein phosphorylation. Curr. Biol. 7: 709-712.

Lukas, J., Herzinger, T., Hansen, K., Moroni, M.C., Resnitzky, D., Helin, K., Reed, S.I., and Bartek, J. 1997. Cyclin E-induced $\mathrm{S}$ phase without activation of the $\mathrm{pRb} / \mathrm{E} 2 \mathrm{~F}$ pathway. Genes \& Dev. 11: 1479-1492.

Lundberg, A.S. and Weinberg, R.A. 1998. Functional inactivation of the retinoblastoma protein requires sequential modification by at least two distinct cyclin-cdk complexes. Mol. Cell. Biol. 18: 753-761.

Ma, T., Van Tine, B.A., Yue, W., Garrett, M., Nelson, D., Adams, P.D., Wang, J., Qin, J., Chow, L.T., and Harper, J.W. 2000. Cell cycle-regulated phosphorylation of p $220^{\text {NPAT }}$ by cyclin E/Cdk2 in Cajal bodies promotes histone gene transcription. Genes \& Dev. (this issue).

Mantagnoli, A., Fiore, F., Eytan, E., Carrano, A.C., Draetta, G.F., Hershko, A., and Pagano, M. 1999. Ubiquitination of p27 is regulated by Cdk-dependent phosphorylation and trimeric complex formation. Genes \& Dev. 13: 1181-1189.

Meeks-Wagner, D. and Hartwell, L.H. 1986. Normal stoichiometry of histone dimer sets is necessary for high fidelity of mitotic chromosome transmission. Cell 44: 43-52.

Meraldi, P., Lukas, J., Fry, A.M., Bartek, J., and Nigg, E.A. 1999. Centrosome duplication in mammalian somatic cells requires E2F and Cdk2-cyclin A. Nat. Cell Biol. 1: 88-93.

Mitchison, J.M. 1971. The biology of the cell cycle. Cambridge University Press, Cambridge.

Morris, L., Allen, K.E., and La Thangue, N.B. 2000. Regulation of E2F transcription by cyclin E-CDK2 kinase mediated through p300/CBP co-activators. Nat. Cell Biol. 2: 232-239.

Nevins, J.R. 1998. Toward and understanding of the functional complexity of the E2F and retinoblastoma families. Cell Growth Diff. 9: 585-593.

Ohtani, K., DeGregori, J., and Nevins, J.R. 1995. Regulation of the cyclin E gene by transcription factor E2F1. Proc. Natl. Acad. Sci. USA 92: 12146-12150.

Ohtsubo, M. and Roberts, J.M. 1993. Cyclin-dependent regulation of $\mathrm{G}_{1}$ in mammalian fibroblasts. Science 259: $1908-1912$.

Ohtsubo, M., Theodoras, A.M., Schumacher, J., Roberts, J.M., and Pagano, M. 1995. Human cyclin E, a nuclear protein essential for the $\mathrm{G}_{1}$ to $\mathrm{S}$ phase transition. Mol. Cell. Biol. 15: 2612-2624.

Osley, M.A. 1991. The regulation of histone synthesis in the cell cycle. Ann. Rev. Biochem. 60: 827-861.

Pagano, M., Pepperkok, R., Verde, F., Ansorge, W., and Draetta, G. 1992. Cyclin A is required at two points in the human cell cycle. EMBO I. 11: 961-971.

Petersen, B.O., Lukas, J., Sorensen, C.S., Bartek, J., and Helin, K. 1999. Phosphorylation of mammalian CDC6 by Cyclin A/CDK2 regulates its subcellular localization. EMBO $J$. 18: $396-410$.

Roberts, S.B., Segil, N., and Heintz, N. 1991. Differential phosphorylation of the transcription factor Oct1 during the cell cycle. Science 253: 1022-1026.

Seghezzi, W., Chua, K., Shanahan, F., Gozani, O., Reed, R., and
Lees, E. 1998. Cyclin E associates with components of the pre-mRNA splicing machinery in mammalian cells. Mol. Cell. Biol. 18: 4526-4536.

Shanahan, F., Seghezzi, W., Parry, D., Mahony, D., and Lees, E. 1999. Cyclin E associates with BAF155 and $\mathrm{BRG}_{1}$, components of the mammalian SWI-SNF complex, and alters the ability of $\mathrm{BRG}_{1}$ to induce growth arrest. Mol. Cell. Biol. 19: 1460-1469.

Sheaff, R.J., Groudine, M., Gordon, M., Roberts, J.M., and Clurman, B.E. 1997. Cyclin E-CDK2 is a regulator of p27Kip1. Genes \& Dev. 11: 1464-1478.

Sherr, C.J. 1993. Mammalian $G_{1}$ cyclins. Cell 73: 1059-1065.

. 1994. $G_{1}$ phase progression: cycling on cue. Cell 79: 551-555.

Sherr, C.J. and Roberts, J.M. 1995. Inhibitors of mammalian $G_{1}$ cyclin-dependent kinases. Genes \& Dev. 9: 1149-1163.

Spruck, C.H., Won, K.-A., and Reed, S.I. 1999. Deregulated cyclin E induces chromosome instability. Nature 401: 297300.

Tanaka, M. and W. Herr. 1990. Differential transcriptional activation by Oct-1 and Oct-2: Interdependent activation domains induce Oct-2 phosphorylation. Cell 60: 375-386.

van den Heuvel, S. and Harlow, E. 1993. Distinct roles for cyclin-dependent kinases in cell cycle control. Science 262: 2050-2054.

Zhang, H.S., Gavin, M., Dahiya, A., Postigo, A.A., Ma, D., Luo, R.X., Habour, J.W., and Dean, D.C. 2000. Exit from $G_{1}$ and $S$ phase of the cell cycle is regulated by repressor complexes containing HDAC-Rb-hSWI/SNF and Rb-hSWI/SNF. Cell 101: 79-89.

Zhao, J., Dynlacht, B., Imai, T., Hori, T.-a., and Harlow, E. 1998. Expression of NPAT, a novel substrate of cyclin E-CDK2, promotes S-phase entry. Genes \& Dev. 12: 456-461.

Zhao, J., Kennedy, B.K., Lawrence, B.D., Barbie, D.A., Matera, A.G., Fletcher, J.A., and Harlow, E. 2000. NPAT links cyclin E-Cdk2 to the regulation of replication-dependent histone gene transcription. Genes \& Dev. (this issue).

Zindy, F., Lamas, E., Chenivesse, X., Sobczak, J., Wang, J., Fesquet, D., Henglein, B., and Brechot, C. 1992. Cyclin A is required in $S$ phase in normal epithelial cells. Biochem. Biophys Res. Commun. 182: 1144-1154. 




\section{Where the cell cycle and histones meet}

Mark E. Ewen

Genes Dev. 2000, 14:

Access the most recent version at doi:10.1101/gad.842100

References This article cites 49 articles, 28 of which can be accessed free at: http://genesdev.cshlp.org/content/14/18/2265.full.html\#ref-list-1

License

Email Alerting Receive free email alerts when new articles cite this article - sign up in the box at the top Service right corner of the article or click here.

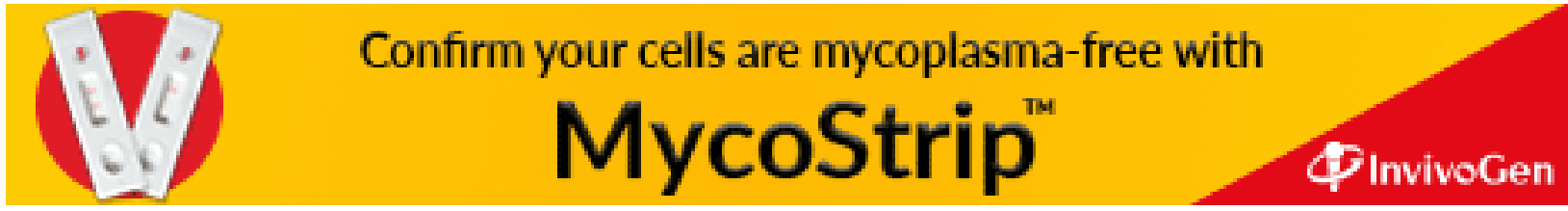

